\title{
Indoor Built Environment
}

\section{No. 1}

Editorial

1 The Impact of Weather on Pollution

Nelson, N. (Bracknell)

Review

5 Health Risk from Indoor Air Pollutants: Public Alarm and Toxicological Reality

Leslie, G.B. (Buckden)

Original Papers

17 The Use of Engineering Controls to Disinfect Mycobacterium tuberculosis and Airbome Pathogens in Hospital Buildings Beggs, C.B.; Donnelly, J.K.; Kerr, K.G.; Sleigh, P.A.; Mara, D.D.; Cairns, G. (Leeds)

28 The Effect of Air Humidification on Symptoms and Nasal Patency, Tear Film Stability, and Biomarkers in Nasal Lavage: A 6 Weeks' Longitudinal Study

Norbäck, D.; Wieslander, G.; Nordström, K.; Wålinder, R.; Venge, P. (Uppsala)

35 Bioaerosol Concentrations in the Quad Cities 1 Year after the 1993 Mississippi River Floods

Curtis, L. (Chicago Ill.); Ross, M. (Research Triangle Park, N.C.); Persky, V.; Scheff, P.; Wadden, R.; Ramakrisnan, V.; Hryhorczuk, D. (Chicago Ill.)

44 Sick Building Syndrome in Mauritius: Are Symptoms Associated with the Office Environment?

Bholah, R.; Fagoonee, I.; Subratty, A.H. (Reduit)

Conference Report

52 Pollens, Particles, Pollution

The 7th National Congress of the Société Française

d'Aérobiologie (SOFRAB), Strasbourg, A pril 12, 2000

Crépat, G.; Fritsch, R. (Dijon)

54 Book Reviews

57 Conference Calendar

\section{No. 2}

Mechanical Ventilation in Buildings

Editors: Phil Jones (Cardiff, UK); John A. Hoskins (Reigate, UK)

Editorial

63 The Rationale for Mechanical Ventilation Jones, P. (Cardiff)
Review

65 Developments in Strategies Used for Natural and Mechanical Ventilation in China

Li, A.G. (Xi'an); Jones, P.J. (Cardiff)

Original Papers

75 An Engineering Approach to Ventilation System Design Dix, T.R. (Birmingham)

87 Super-Efficient Mechanical Ventilation Berry, J. (London)

97 Ventilation for People Brundrett, G. (Kingsley)

102 Mechanical Ventilation and Fabric Thermal Storage Braham G.D. (Ifield)

111 The Prediction of Airflow-Generated Noise in Mechanical Ventilation Systems

Waddington, D.C.; Oldham, D.J. (Liverpool)

118 Economic Comparison of Two Energy-Efficient Design Strategies for Mechanical Ventilation Systems Vishnevsky, E.P. (Saint Petersburg)

\section{No. 3-4}

Editorial

123 Making Sure We're 'Safe as Houses' Harrison, P.T.C.; Holmes, P. (Leicester)

Original Papers

127 The Use of Heat Pumps to Induce Airflow on Hot Days in Otherwise Passive Ventilation Systems - A Zonal Modelling Approach

Gage, S.A.; Ayres, P.; Axon, J. (London)

143 Energy Saving and Airtightness of Blocks of Flats in Lithuania Juodis, E. (Vilnius)

148 Effect of Thermal Comfort/Discomfort due to Infrared Heaters Installed at Workplaces in Industrial Buildings Petráš, D.; Kalús, D. (Bratislava)

157 Willingness to Pay for Renewable Energy: Implications for UK Green Tariff Offerings

Batley, S.L.; Fleming, P.D.; Urwin, P. (Leicester)

171 Modelling of Emissions of Total Volatile Organic Compounds in an Australian House Guo, H.; Murray, F. (Perth, W.A.)

182 A Macroscopic Model for Predicting Dust Concentration Distribution in Swine Buildings

Puma, M.C. (Ames, Iowa); Maghirang, R.G. (Manhattan, Kans.)

KARGER @ 2001 S. Karger AG, Basel

Fax + 41613061234 E-Mail karger@karger.ch Access to full text and tables of contents, E-Mail karger@karger.ch including tentative ones for forthcoming issues: www.karger.com/journals/ibe/ibe_bk.htm 
192 A Study of Area and Personal Airbome Asbestos Samples Abatement in a Crawl Space

Lange, J.H.; Kuhn, B.D. (Erie, Pa.); Thomulka, K.W. (Philadelphia, Pa.); Sites, S.L.M. (Chambersburg, Pa.)

201 Cost and Distribution of Bids for Asbestos Abatement Projects in the Public Sector Lange, J.H. (Pittsburgh, Pa.)

207 Effectiveness of Engineering Controls for Airborne Lead Exposure during Renovation/ Demolition of a Commercial Building

Lange, J.H. (Pittsburgh, Pa.); Thomulka, K.W. (Philadelphia, Pa.)

216 Monitoring of Ambient Volatile Organic Compounds at Two Urban Sites in Hong Kong from 1997 to 1998

Sin, D.W.M.; Wong, Y.C.; Louie, P.K.K. (Hong Kong)

228 Characterisation of Gas Phase Organic Emissions from Hot Cooking Oil in Commercial Kitchens

To, W.M.; Yeung, L.L.; Chao, C.Y.H. (Hong Kong)

233 Formaldehyde in Occupied and Unoccupied Caravans in Australia

Dingle, P.; Tan, R.; Cheong, C. (Murdoch, W.A.)

Letters to the Editor

237 Suicide by Carbon Monoxide in Australia Bouvier, R. (Kew)

238 Suicides and Carbon Monoxide Harrison, P. (Leicester)

239 Europe-Wide Research Inventory on the Indoor Environment Harrison, P. (Leicester)

240 Conference Calender

No. 5

Editorial

241 The Threat Posed by Airborne Micro-Organisms Beggs, C.B.; Kerr, K.G. (Leeds)

Review

246 Environmental Tobacco Smoke and Respiratory Health in Children: A Critical Review and Analysis of the Literature from 1969 to 1998

Witorsch, R.J. (Richmond, Va.); Witorsch, P. (Washington, D.C.)

Original Papers

265 Size Distribution of Polycyclic Aromatic Hydrocarbons in Indoor Airbome Particulates

Sugiyama, T.; Amagai, T.; Matsushita, H.; Soma, M. (Shizuoka)

277 Gravimetric Studies on VOC Adsorption by Indoor Materials under Near-Ambient Conditions

Meininghaus, R.; Kirchner, S.; Maupetit, F.; Sallée, H.; Quenard, D. (Marne-la-Vallée)

284 Passive Downdraught Evaporative Cooling. I. Concept and Precedents

Bowman, N.T.; Eppel, H.; Lomas, K.J.; Robinson, D.; Cook, M.J. (Leicester)
Conference Reports

291 Intemational Conference on Sustainable Building 2000. Maastricht, The Netherlands, October 22-25, 2000

Jones, P. (Cardiff)

293 Report on 4th International Conference on Energy for Buildings. Vilnius, Lithuania, September 21 and 22, 2000 Juodis, E. (Vilnius)

296 Indoor Air Cleanliness: Bioaerosols and Particulates in Indoor Air - Health Effects: The Role of Ventilation. Seminar held at the Chartered Institute of Building Services Engineers, Balham, November 8, 2000

Hoskins, J.A. (Reigate)

298 Book Reviews

300 Conference Calendar

No. 6

Editorial

301 All the Perfumes of Arabia

Hoskins, J.A. (Reigate)

Original Papers

303 Revisiting the Association between Environmental Tobacco Smoke Exposure and Lung Cancer Risk. I. The Dose-Response Relationship with Amount and Duration of Smoking by the Husband

Fry, J.S.; Lee, P.N. (Sutton)

317 A Simple Interface to Computational Fluid Dynamics Programs for Building Environment Simulations

Broderick III, C.R.; Chen, Q. (Cambridge, Mass.)

325 Passive Downdraught Evaporative Cooling. II. Airflow Modelling Cook, M.J.; Robinson, D.; Lomas, K.J.; Bowman, N.T.; Eppel, H. (Leicester)

335 Lighting Quality Surveys in Office Premises Chung, T.M.; Burnett, J. (Hong Kong)

342 A Survey of Publicly Funded Asbestos Abatement Projects in the County of Erie, Pennsylvania, USA, during the Time Period 1996-1999

Lange, J.H.; Bules, M.; Lindquist, J.; Gray, M.; Ivarone, C. (Erie, Pa.)

Conference Report

348 Health and Well-Being: Does Our Environment Matter? Institute for Environment and Health Annual Seminar, Held at the NSPCC National Training Centre, Leicester, UK, November 28, 2000

Green, E. (Leicester)

351 Book Reviews

354 Conference Calendar

355 Author Index Vol. 9, 2000

356 Subject Index Vol. 9, 2000 